\title{
Inkonsistensi Mazhab Dalam Penafsiran Ayat-Ayat Hukum Tafsir Al-Qurtubi
}

\author{
Oleh: M. Najib Tsauri \\ m.najib_tsauri@uinjkt.ac.id
}

Abstrak: Problem utama yang didiskusikan dalam tulisan ini adalah didasari atas tendensi mufassir kebanyakan terhegemoni akan mazhabnya sendiri. Ini yang menjadi perhatian utama oleh penulis untuk mengkaji sosok al-Qurțbī. Penelusuran dimulai dengan mengenal al-Qurțbī, penafsiran al-Qurțubī terhadap ayat hukum sekaligus menganalisa ragam penafsiran dan melacak konsisten tidaknya dalam bermadzab ketika dihadapkan dalam sebuah kasus. Karena konsistensi fanatisme mazhab dalam proses menafsirkan ayat-ayat hukum merupakan perkara yang perlu diambil perhatian, kerana ia melibatkan permasalahan hukum dan perbedaan pendapat antara empat mazhab yang masyhur.

Keywords: Mazhab, Hukum, Al-Qurțubī

\section{A. Pendahuluan}

Pada hakekatnya, semua yang tersurat dalam teks alQur'an merupakan ajaran yang harus dipegang oleh umat Islam, karena memiliki kandungan yang mencakup petunjuk dan pedoman hidup dalam meraih kebahagiaan dunia dan akhirat, baik dalam bentuk ajaran teologi, moral (etika), hukum, politik, ibadah, falsafah, sosial, mu'ämalah dan sebagainya. Namun, untuk menerjemahkan teks yang tersurat pada al-Qur'an dalam kehidupan sehari-hari, seseorang tidak cukup hanya membaca dan mendendangkannya dengan lagu merdu. Tetapi lebih dari itu, dibutuhkan pemahaman dan upaya untuk mengungkapkan isi dan hikmah kandungannya. Upaya inilah yang biasa disebut dengan "tafsir". Inilah satu alasan seperti yang dinyatakan Muhạmmad 'Alī al-Ṣābūnī bahwa tafsir merupakan kunci untuk membuka gudang harta karun yang tertimbun dalam al-Qur'an. ${ }^{1}$ Maka tanpa kunci (tafsir) itu, seseorang tidak akan mampu 
untuk membuka gudang tersebut dan mendapat mutiara dan permata di dalamnya.

Dalam literatur metode tafsir dikatakan bahwa banyak sekali ahli tafsir dan masing-masing menempuh cara pilihannya sendiri. Mereka berusaha untuk mengetahui pemahaman sebuah ayat dengan cara menafsirkan melalui riwayat sahabat seperti ini dikenal di kalangan para ahli tafsir dengan sebutan tafsīr bi alma'thūr. ${ }^{2}$ Atas dasar itulah muncul pegangan dalam metode penafsiran, yaitu dikenal dengan tafsīr bi al-ra'yi, ${ }^{3}$ sebuah metode yang bersandarkan pada akal dan pemahaman dalam merenungi maksud dan tujuan dari makna yang tersurat dengan menggunakan ilmu-ilmu perangkat khusus sebagai kelengkapan untuk mencapai kepada pemahaman makna yang tersirat. ${ }^{4}$ Diantara mereka ada yang menitikberatkan kepada riwayatriwayat hadis, seperti al-Tabar $\overline{1}^{5}$ atau yang menekuni soal balāghah (retorika dan ketinggian mutu bahasa) seperti alZamakhsharī, ${ }^{6}$ atau yang mencurahkan pembahasan tentang masalah filsafat dan ilmu kalam (teologi), seperti al-Rāzī dalam tafsirnya Mafätih al-Ghaib, ${ }^{7}$ atau yang menitikberatkan penafsirannya terhadap ayat-ayat tashri $\bar{l}^{\prime}$ seperti al-Qurțubī, Ibn al-'Arabī, al-Jașșāṣ dan Șiddīq Hasan Khān. ${ }^{8}$ Ada juga yang menitikberatkan pembahasan kepada isyarat-isyarat al-Qur'an yang berpautan dengan ilmu suluk dan tasawuf, seperti tafsīr alTastarī buah karya Abū Muhammad Sahl Ibn 'Abdullāh alTastarī, Rūh al-Ma' ān̄̄ buah karya al-Alusîn dan banyak lagi aliran-aliran tafsir yang menggeluti di bidangnya.

Setidaknya hingga kini, ketika berbicara tentang metodologi tafsir al-Qur'an, banya orang merujuk pada alFarmāwī. Dari berbagai aliran-aliran tafsir tersebut, al-Farmāwī mengklasifikasikan tahap perkembangan tafsir, menurutnya ada beberapa bidang kecenderungan mufassir. Kecenderungan yang dimaksud antara lain; 1). Tafsir șufi (sufistik) yaitu kecenderungan mufassir untuk mengungkap sisi mistik dalam al-Qur'an melalui pendekatan tasawuf. ${ }^{10}$ Kecenderungan ini diwarnai dua aliran dalam penafsiran al-Qur'an, yaitu aliran tasawuf teoritis (nadarī) dan aliran tasawuf praktis ('amalī). ${ }^{11}$ 2). Tafsir falsafì yaitu kecenderungan mufassir untuk mengungkap sisi penafsiran ayat-ayat al-Qur'an berdasarkan 
logika atau pemikiran yang bersifat liberal dan radikalmelalui pendekatan filsafat. 3). Tafsir 'ilm $\bar{\imath}$ yaitu kecenderungan mufassir untuk mengungkap sisi fenomena-fenomena alam dalam al-Qur'an dengan didukung berbagai cabang ilmu pengetahuan melalui pendekatan ilmiah. 4). Tafsir fiqh yaitu kecenderungan mufassir untuk mengungkap sisi hukum-hukum atau aturan-aturan dalam al-Qur'an melalui pendekatan fikih. 5). Tafsir adabi ijtim $\bar{a} \bar{l}$ yaitu kecenderungan mufassir untuk mengungkap sisi keindahan bahasa al-Qur'an dan mukjizatmukjizatnya; menjelaskan makna-makna dan maksudmaksudnya; memperlihatkan aturan-aturan al-Qur'an tentang kemasyarakatan; dan mengatasi persoalan-persoalan lain dengan pendekatan sosio-kultur.

Dari kecenderungan di atas, penulis tertarik pada tafsir yang berorientasi pada hukum ( $\left.\operatorname{tash} r \bar{\imath}^{\top}\right)$. Sehubungan dengan perkembangan tafsir, al-Fārmawī menjelaskan terkait lahirnya tafsir fikih. Bersamaan dengan lahirnya tafsìr al-ma'thūr, lahirlah tafsir fikih. Keduanya dinukil secara secara bersamaan tanpa dibeda-bedakan. Hal ini terjadi tatkala para sahabat menemukan kemuskilan dalam memahami al-Qur'an, Nabi saw. lalu menjelaskan. Setelah Nabi saw. wafat, para sahabat berijtihad menggali sendiri hukum-hukum syara' dari al-Qur'an, hal ini terjadi ketika para sahabat menghadapi permasalahanpermasalahan yang belum terjadi pada masa Nabi saw. ${ }^{13}$ Demikian pula pada generasi sahabat. Pendapat-pendapat para sahabat dan para tabi'in kebanyakan berkenaan dengan persoalan hukum. Pembukuan tafsir fikih ini terjadi pada abad ke-2 $\mathrm{H}$, tetapi -sejalan dengan perkembangan fikih sendiritafsir dalam bentuk ini berkembang pesat setelah lahirnya mazhab-mazhab fikih. ${ }^{14}$

Dalam perkembangan selanjutnya, para ulama pengikut mazhab tertentu menafsirkan ayat-ayat ahkām (hukum) dalam al-Qur'an sesuai dengan teori istinbāt (penetapan) hukum yang berlaku di dalam mazhabnya. Tidak jarang mereka menafsirkan ayat al-Qur'an untuk membenarkan pandangan mazhab yang mereka anut dengan mencoba menyesuaikan al-Qur'an dengan mazhab mereka sendiri. ${ }^{15}$ M. Quraish Shihab berpendapat bahwa tafsir fikih atau tafsir al-ahkām adalah penafsiran- 
penafsiran yang berdasarkan ayat-ayat hukum. ${ }^{16}$ Hal yang lebih mendalam lagi seperti yang dikemukakan oleh al-Qațān, yang dimaksud dengan tafsir fikih atau tafsir al-ahkām ialah penafsiran terhadap ayat-ayat al-Qur'an yang khusus membahas ayat-ayat hukum dan di dalamnya fanatisme mazhab sering kali mewarnai dan mempengaruhi dalam penafsiran. ${ }^{17}$ Hal tersebut, sesuai dengan karakter fikih yang di dalamnya mengandung perbedaan pendapat, maka pada tafsir al-aḥkām pun di dalamnya terdapat perbedaan pendapat para mufassir dalam menafsirkan suatu ayat hukum.

Dari beberapa buku menyebutkan macam-macam tafsir yang berorientasi kepada hukum, seperti, Ahkām al-Qur'ān karya al-Jașșāṣ (w. 370 H/980 M), Ahkām al-Qur'ān karya alKiyā al-Harasī (w. 504 H/1110 M), Ahkkām al-Qur'ān karya Ibn al-'Arabī (w. 543 H/1148 M), ${ }^{18}$ al-Jāmi' li Ahkām al-Qur'ān karya Imām al-Qurțubī (w. 671 H/1273 M), Rawāi al-Bayān fì Tafsīr Ayat al-Ahkām karya 'Alī al-Șābūnī (1347 H/1928 M), ${ }^{19}$ dan Tafsīr Ayat al-Aḥkām karya Muḥammad 'Alī al-Sāyis (w. $1396 \mathrm{H} / 1976 \mathrm{M}){ }^{20}$

Sering terjadi, ketika para mufassir menafsirkan sebuah ayat al-Qur'an tidak lepas dari berbagai pengaruh, baik dari lingkungan, kondisi sosial, ataupun guru yang ia anut misalnya, sehingga dipengaruhi oleh aliran pemikiran yang berbeda-beda, ataupun mazhab yang dianut sehingga menjadi tolok ukur dalam memutuskan atau menyimpulkan sebuah pendapat ketika menafsirkan al-Qur'an. Akan tetapi, ada juga mufassir yang lebih subjetif ketika mengambil pendapat dari mazhab-mazhab, walaupun jati dirinya pengikut mazhab tertentu.

Sehubungan dengan tendensi mufassir, berikut beberapa contoh mengenai hal tersebut, tidak lain adalah al-Jașșāṣ, ia sangat fanatik terhadap mazhab Hanafì dalam membahas masalah-masalah fikih dan politik khilafah. Ia juga mempunyai kesamaan pandangan dengan Syi'ah. ${ }^{21}$ Al-Kiyā al-Harasī̄, ia menyatakan dalam muqadimah Ahkām-nya, ia sangat jelas, memberikan dukungan terhadap mazhab Imām Shāfi' '̄, baik dari segi ușūl maupun furū ${ }^{22}$ Ibn al-'Arabī, karena ia adalah salah seorang pengikut mazhab Imām Mālik, ia sangat terpengaruh dengan mazhabnya dalam penafsirannya, sekaligus sangat 
fanatik dan sering membelannya. ${ }^{23}$ Konsistensi fanatisme mazhab dalam proses menafsirkan ayat-ayat hukum merupakan perkara yang perlu diambil perhatian, kerana ia melibatkan permasalahan hukum dan perbedaan pendapat antara empat mazhab yang masyhur. ${ }^{24}$

Berangkat dari tendensitas mufassir-mufassir tersebut, Muhammad 'Alī Iyāzī memaparkan dalam karyanya alMufassirūn Hayatuhum wa Manhajuhum, bahwa tafsir alQurțubī adalah salah satu tafsir yang paling banyak membahas persoalan-persoalan hukum fikih. Karena itu, tafsirnya dikenal sebagai tafsir yang bercorak fikih. ${ }^{25}$ Sekaligus, al-Qurțubī adalah salah satu pengikut mazhab fikih Imām Mālikī sebagaimana Ibn al-`Arab̄̄ yang bermazhab Imām Mālikī, al-Kiyā al-Harasī yang bermazhab Imām Shāfi'ī dan al-Jașșāṣ bermazhab Imām Hanafî.

Apabila dibandingkan dengan beberapa mufassir-mufassir lainnya yang menafsirkan al-Qur'an hanya dengan membatasi pada ayat-ayat hukum, maka tafsir al-Qurțubī tergolong tafsir hukum terlengkap karena al-Qurțubī menafsirkan keseluruhan ayat al-Qur'an sesuai urutan mushaf. Namun yang menjadi akar permasalahan di sini adalah kebanyakan mufassir cenderung terhegemoni akan mazhabnya sendiri. Penulis meneliti sosok alQurțubī, dalam penafsirannya apakah ia konsisten terhadap mazhabnya atau tidak? Sehingga fanatisme mazhab menjadikan akar keterpengaruhan terhadap penafsirannya. Sebab semua tafsir ahkam dipastikan memiliki corak fiqh, begitu pula halnya tafsir al-Qurțubī. Sekalipun demikian, dalam pandangan penulis tafsir al-Qurțubī memiliki corak fiqh yang khas, yang berbeda dengan tafsir ahkam lainnya.

\section{B. Biografi Singkat Al-Qurțubī}

Menurut Faizah Ali Syibromalisi dan Jauhar Azizy, nama al-Qurțubī dicantumkan dalam biografi mufassir, seperti kitab Tabaqat al-Mufassirīn karya al-Suyuțī merujuk pada 6 orang. Mereka adalah; Baqī bin Makhlad bin Yazīd Abū 'Abd alRaḥmān al-Andalusī al-Qurțubī (201-276 H/816-889 M), 'Abd al-Jalīl bin Mūsá bin 'Abd al-Jalīl Abū Muḥammad al-Anșārī alAndalusī al-Qurțubī (w. 608 H/1211 M), 'Abd al-Raḥmān bin Marwān bin 'Abd al-Raḥmān al-Anșārī al-Qurțubī (341-413 
H/952-1022 M), Ubaydullāh bin Muḥammad bin Mālik Abū Marwān al-Qurțubī (340-400 H/ 951-1009 M), Abū 'Abdillāh Muhammad bin Aḥmad al-Anșārī al-Mālikī al-Qurțubī (w. 671 H/1273 M), Muhammad bin Umar bin Yūsuf al-Qurțubī (558$631 \mathrm{H} / 1162-1233 \mathrm{M}){ }^{26}$

Tokoh tafsir al-Qurtubī yang dimaksud penulis adalah Abū 'Abdillāh Muhammad bin Aḥmad al-Anșārī al-Mālikī alQurțubī (w. $671 \mathrm{H} / 1273 \mathrm{M}$ ). ${ }^{27}$ Ia adalah ulama yang terkenal di masanya dan setelahnya. ${ }^{28}$ Ia lahir pada tahun $580 \mathrm{H} . / 1184 \mathrm{M}$. pada masa kekuasaan Bani Muwaḥhidūn, di sebuah desa bernama Qurtubah di Cordova, Andalusi (sekarang Spanyol). Di sanalah ia mempelajari bahasa Arab, syair, al-Qur'an al-Karim, fikih, naḩwu, qira'at, ilmu balāghah, 'ulūm al-Qur'ān, dan juga ilmu-ilmu lainnya. Setelah itu, ia datang ke Mesir dan menetap di sana, al-Qurțubī berguru dengan Ibn al-Jumayzī dan al-Ḥasan al-Bakrī. $^{29}$

Sejak kecil, ia hidup dalam lingkungan keluarga yang sederhana. Ayahnya adalah seorang petani yang sering sibuk di ladang pertaniannya. Pertanian adalah bidang yang ditekuni ayahnya dan telah menjadi bagian dari keseharian hidupnya yang selalu dijalaninya dengan penuh senyuman. Kira-kira kurang lebih lima belas tahun, tepatnya pada tahun $580 \mathrm{H}$ sampai tahun $595 \mathrm{H}$, al-Qurțub̄ tumbuh besar bersama ayahnya. ${ }^{30}$ Setelah hijrah ke Mesir untuk mengembangkan intelektualnya dan di sana ia meninggal dunia pada malam senin, tepatnya pada tanggal 9 Syawal tahun $671 \mathrm{H}$. Makamnya berada di al-Maniyā, di Timur sungai Nil dan berbagai kalangan sering kali mengunjungi makamnya. Sehingga pada tahun 1971 $\mathrm{M}$ di sana dibangun sebuah masjid yang diberi nama masjid alQurțubīi ${ }^{31}$

\section{Mazhab Fikih Al-Qurțubī}

Pada masa pembentukan mazhab, beragam peristiwa yang menimpa kaum Muslim mengantarkan pada pembentukan hukum-hukum yang sebelumnya mungkin tidak pernah ada. Maka masing-masing imam mazhab melakukan analisis terhadap kejadian ini berdasarkan sandaran al-Qur'an dan alSunnah, serta sumber-sumber ijtihad lainnya. Dengan itu, para 
imam memberikan keputusan hukum yang telah melalui pertimbangan pemikiran di dalam hatinya, dan meyakini bahwa hal yang dihasilkan itu merupakan sesuatu yang benar, yang didasarkan pada dalil-dalil dan argumentasi. ${ }^{32}$

Penulis beranggapan bahwa munculnya tafsir bercorak fikih adalah sebagai bentuk pengaruh yang berlangsung di dunia Islam khususnya dalam bidang tafsir. Ini terjadi lantaran kebanyakan masalah muncul dan menjadi bahan pertanyaan oleh para sahabat kepada Nabi saw. sampai pada generasi selanjutnya adalah masalah yang berkaitan dengan aspek hukum. Di sini, keputusan hukum yang bersumber dari al-Qur'an bisa muncul dengan cara melakukan penafsiran terhadapnya. Maka dari itu, di mana pengaruh suatu mazhab tidak bisa dilepaskan dari perkembangan peradaban dan pemikiran seorang mufassir.

Dalam kitab Tārikh Tashri' al-Islamī karya Rashād Ḥasan Khalīl mengatakan bahwa murid-murid Imām Mālik adalah Ashhāb bin 'Abd al-'Azīz al-Qaisī, rujukan kaum Muslim di Mesir dalam bidang fikih dan Tunisia yang wafat pada tahun $224 \mathrm{H}$. Selain itu ada juga Abū al-Ḥasan al-Qurțubī, yang belajar kitab al-Muwatța secara langsung kepada Imām Mālik dan menyebarkannya di Andalusia. ${ }^{33}$ Dari proses penyebaran inilah mayoritas menjadi mazhab resmi negara sekaligus keterpengaruhan inilah Imām al-Qurțubī menjadikan Mālikī sebagai mazhab yang dianutnya.

Dalam bidang fikih, Spanyol Islam memang dikenal sebagai panganut mazhab Mālikī. Yang memperkenalkan mazhab di sana; yaitu Ziyād bin 'Abd al-Raḥmān bin Shibțūn (w. 199 H/804 M) dan al-Ghāzī bin Qais (w. 209 H/ 814 M). Perkembangan selanjutnya ditentukan oleh faktor Yahyá bin Yahyá al-Laithī yang menjadi $q \bar{a} d i$ pada masa Hishām bin 'Abd al-Raḥmān yang juga memiliki semangat untuk menyebarkan mazhab tersebut. ${ }^{34}$ Dari masa ke masa mazhab ini selalu menjadi mazhab resmi Negara. Bahkan pada masa kekuasaan alMurābițūn -yang terdiri dari para mu'allaf yang mewarasi tradisi Barbar yang belum punah- muncul ledakan gairah keagamaan fanatik di awal abad ke-12 yang pada gilirannya merugikan kaum Kristen, Yahudi bahkan kaum Muslim liberal. Di bawah kekuasaan 'Alī yang Saleh (1106-1143 M), putra 
sekaligus penerus Yūsuf bin Tāshifīn, karya-karya al-Ghazālī dimasukkan dalam daftar hitam bahkan dibakar karena beberapa pandangannya dianggap menghina para fāqīh termasuk mazhab Mālikī yang merupakan mazhab resmi pemerintah Murābitūn. ${ }^{35}$ Dari kondisi lingkungan inilah terutama keluarga, al-Qurțubī mengikuti mazhab Mālikī yang memang didominasi oleh mazhab itu, karena dari faktor itu merupakan pilihan yang secara sadar dilakukannya dengan mempertimbangkan aspekaspek keilmiahan.

Berdasarkan latar belakang mazhab al-Qurțubī, ia tetap pada pendiriannya untuk mengikuti mazhab Mālik̄̄ yang dianutnya, akan tetapi ia tidak terhegemoni dan tidak fanatis (lam yata'aṣub) pada mazhabnya. Baginya mazhab Mālik̄̄ merupakan warisan pemikiran dan tamadun dari para ulama dalam penyebaran Islam di Andalusia (khususnya di tanah kelahirannya) ketika itu. Ini dibuktikan dari hasil pelacakan penulis, seorang peneliti tentang tokoh al-Qurțub̄̄, yakni AlQașabī Mạ̣mūd Zalaṭ dalam karyanya menyatakan bahwa, ketika al-Qurțubī menafsirkan ayat tentang pokok masalah apapun ia justru sering keluar dari jalur mazhab Mālikī ketika ada pendapat yang tidak benar. Oleh karena itu ia lebih memilih mazhab lainnya yang menurutnya lebih benar $(s a h \bar{h} h) .{ }^{36}$

\section{Menelusuri Mazhab Guru-guru Al-Qurțubī}

Menurut Aḥmad 'Isá Yūsuf al-'Isá dalam kitab "al-Arā alUșūliyyati l̄̄ Imām al-Qurțub̄ min Khilāli Tafsīrihi”, ia mengatakan bahwa Imām al-Qurțubī telah berguru kepada beberapa guru yang mereka hidup di dua negara yaitu di Andalusia dan Mesir. Guru ia di Andalusia mereka adalah: ${ }^{37}$

a. Abū Ja'far Aḥmad bin Muhammad al-Qaisī yang dikenal dengan nama Ibn Abī Hujjah (w. 643 H/1245 M).

b. Rabī' bin 'Abd al-Rạ̣mān bin Aḥmad bin 'Abd alRaḥmān 'Ibn al-Rabīe al-Ash'ārī (w. 633 H/1236 M).

c. Abū Hasan bin 'Al̄̄ bin 'Abdullāh bin Muhammad bin Yūsuf al-Anșārī (w. 651 H/1253 M).

d. Abū 'Amir Yaḥyá bin 'Abd al-Raḥmān bin Ạ̣mad bin Man̄̄ al-Ash’arī (w. 638 H/1241 M). 
Adapun beberapa guru yang ada di Mesir adalah: ${ }^{38}$

a. Rāshid al-Dīn Abū Muḥammad 'Abd al-Wahhāb bin Rawāj bin Zāâir bin Futūḥ al-Iskandarī al-Mālikī (w. $648 \mathrm{H} / 1250 \mathrm{M})$.

b. Bahā' al-Dīn Abu al-Hasan 'Alī bin Habatullāh bin Salāmah al-Lakhmī al-Mișrī al-Shāfi'̄̄ (w. 649 $\mathrm{H} / 1252 \mathrm{M})$.

c. Abū al-'Abbās Aḥmad bin 'Umar bin Ibrahīm alMālikī al-Qurțubī al-Anșarī (w. 656 H/1258 M).

d. Al-Hasan bin Muḥammad bin Muhammad bin 'Amrūk al-Taimī al-Naysāburī al-Dimshaqī, atau dipanggil dengan nama Abū 'Alī Șadr al-Dīn al-Bakrī (w. $656 \mathrm{H} / 1258 \mathrm{M}$ ).

Seorang mufassir tidak lepas dari seorang guru yang pernah memberikan ilmu sekaligus memberikan sumbangsi terhadap pengaruh pemikirannya. Dalam pengantar tafsir alQurțubī dijelaskan guru-guru yang lebih kuat pengaruhnya, ${ }^{39}$ sehingga al-Qurțubī menjadi ulama yang sangat produktif dengan berbagai karya-karya yang cukup banyak. Guru-gurunya adalah: pertama, Rāshid al-Dīn Abū Muḥammad 'Abd alWahhāb bin Rawāj bin Zāfir bin Futūḥ al-Iskandarī al-Mālik̄̄ (w. $648 \mathrm{H} / 1250 \mathrm{M}$ ). Ia dilahirkan di Iskandariyah, ia adalah imām al-muhaddīth (ahli hadis). Al-Qurțubī belajar banyak kepada Ibn Rawāj dalam bidang hadis. Kedua, Bahāe al-Dīn Abū al-Hasan 'Alī bin Habatullāh bin Salāmah al-Lakhmī alMișrī al-Shāfi' '̄ (w. 649 H/1252 M). Ia lahir di Mesir dan lebih dikenal dengan sebutan Ibn al-Jumaizī, salah seorang ahli dalam bidang hadis, fikih dan ilmu qira'at. Ia juga seorang faqīh mazhab Shāfi'̄i di Mesir. Ketiga, Abū al-'Abbās Aḥmad bin 'Umar bin Ibrahīm al-Mālikī al-Qurțubī al-Anșarī (w. 656 H/1258 M). Ia lahir di Cordoba. Ia adalah seorang ahli hadis dan faqīh Mālikī. ${ }^{40}$ Keempat, Al-Ḥasan bin Muhammad bin Muḥammad bin 'Amrūk al-Taimī al-Naysāburī al-Dimshaq̄î, atau dipanggil dengan nama Abū 'Alī Șadruddīn al-Bakrī (w. 656 H/1258 M). Ia lahir di Damaskus. Ia adalah ahli sejarah dan muhaddīth. ${ }^{41}$ Berangkat dari pencarian ilmu dari para ulama, 
kemudian al-Qurțubī diasumsikan berhasrat besar untuk menyusun sebuah kitab tafsir yang bernuansa fikih.

Dari data-data guru al-Qurțubī di atas, penulis menemukan satu guru yang menjadi rujukan dalam penafsiran al-Qurțubī, yakni Abū al-'Abbās. Bisa dibuktikan ketika al-Qurțub̄̄ menafsirkan QS. al-Baqarah: 223. ${ }^{42}$ Pembahasan mengenai hukum larangan menggauli istri melalui dubur/anus. Dari penafsiran ini, ada beberapa argumentasi oleh pihak yang

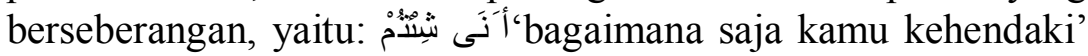
mencakup beberapa jalur -anus dan vagina- melalui keumumannya. Perlu diketahui bahwa dalil tersebut tidak mengandung argumentasi apapun. Al-Qurțubī dengan jelas mengutip pendapat hadis yang dihimpun oleh Abū al-Farj Ibn al-Jawzī berikut jalur-jalur periwayatannya dalam sebuah kitab

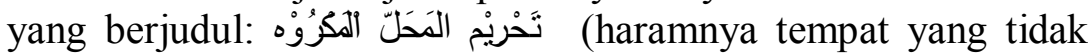
disukai/anus). Juga hadis yang dihimpun oleh guru kami, Abū

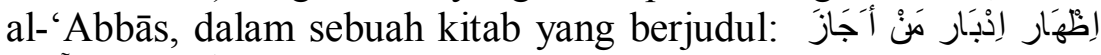
(bantahan terhadap pendapat yang membolehkan bersetubuh melalui Anus. Al-Qurțub̄̄ menegaskan bahwa pendapat ini yang benar berdasarkan hadis-hadis sahih. ${ }^{43}$

Pandangan penulis sangat jelas bahwa ketika al-Qurțubī hijrah ke Mesir (yang pada waktu itu kekuasaan dipegang oleh dinasti al-Ayyūbiyyīn), karena Mesir saat itu adalah negara yang dipenuhi para ulama dari berbagai penjuru dunia Islam. Pada saat itulah ia bertemu dan belajar langsung kepada gurugurunya. Ketika di Mesir al-Qurțubī belajar kepada guru dengan banyak perbedaan mazhab, bisa dikatakan guru-gurunya adalah penganut mazhab yang berbeda-beda pula. Ini jelas ketika alQurțubī menafsirkan ayat hukum, ia tidak terlalu ta'ashub dan justru cenderung bersifat adil.

\section{Penafsiran Ayat-ayat Hukum}

\section{Kesaksian dalam Pernikahan.}

Penulis menguraikan penafsiran al-Qurțubī tidak konsisten dengan mazhabnya. Bisa dilihat saat ia menafsirkan QS. al-Baqarah [2]: 221, ${ }^{44}$ al-Qurțubī menjelaskan bahwa menurut Imām Mālik kesaksian bukanlah syarat atau hal yang 
diwajibkan dalam pernikahan, sebab Allah swt. tidak menyebutkan harus ada kesaksian dalam pernikahan. Akan tetapi yang diharuskan dalam pernikahan adalah publikasi dan pengumuman, yang tujuannya adalah untuk memelihara garis keturunan (anak), maka hal itu sudah mencukupi keabsahannya. Dengan pernyataan tersebut, al-Qurțubī tidak sejalan dengan Imām Mālik dan menyatakan bahwa pendapat Imām Shāfi'’̄ yang lebih kompatibel dan lebih kuat karena didukung dengan

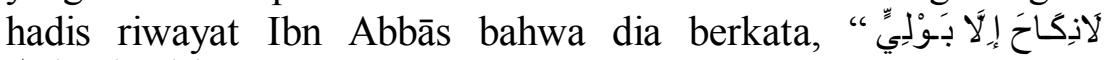
وَشَاهِيْنَبْ عَدْلِ (tidak sah sebuah pernikahan kecuali dengan seorang wali dan dua orang saksi). Menurutnya, tidak ada seorang sahabat pun berbeda pendapat dengan Ibn Abbās. ${ }^{45}$ Dari penafsiran tersebut, ini menunjukkan bahwa al-Qurțubī sangat selektif dalam mengutip sebuah pendapat dengan melihat kasuskasus tertentu.

\section{Pembunuhan yang Menitikberatkan pada Hukuman Qiṣāṣ.}

Al-Qurtubī menjelaskan QS. al-Baqarah [2]: $178^{46}$ adalah sebagai penetapan untuk melaksanakan hukuman qiṣāṣ walaupun telah diganti dengan diyat. ${ }^{47}$ Dengan berbagai pertimbangan, al-Qurțubī mengutip pendapat yang disampaikan oleh al-Bukhārī dari al-Ḥumaidī, dari Sufyān, dari 'Amrū, dari Mujāhid, dari Ibn 'Abbās. ${ }^{48}$ Menurutnya, ayat ini diturunkan kepada dua qabilah di antara qabilah-qabilah yang berada di negeri Arab, dua qabilah itu saling bertikai, lalu mereka menetapkan hukuman pembunuhan itu dengan cara membunuh sahaya laki-laki untuk seorang laki-laki yang dibunuh dan hamba sahaya wanita untuk seorang wanita yang dibunuh. Begitu juga disampaikan oleh Qatādah. ${ }^{49}$

Al-Qurțubī menguti sabda Rasulullah saw., ${ }^{50}$

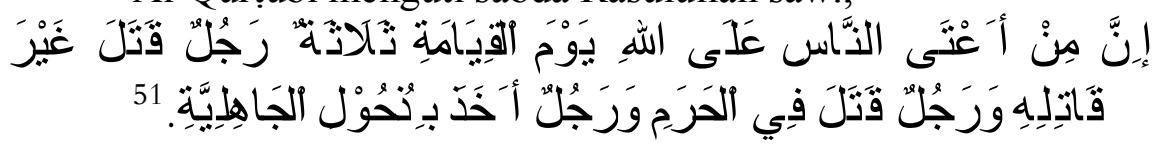

Sejalan pendapat di atas, al-Qurțubī mengutip keterangan Qatādah, al-Sha'bī dan ulama lainya, ia mengatakan bahwa ada permusuhan penduduk jahiliyah antara dua qabilah (suku) Arab. 
Di antara mereka ada yang terbunuh dan ada yang luka-luka, bahkan mereka membunuh hamba sahaya dan wanita. Mereka belum sempat membalas dendam karena mereka masuk Islam. Mereka menyatakan tidak rida apabila hamba-hamba sahaya yang terbunuh itu tidak diganti dengan orang merdeka, wanita diganti dengan pria. Tradisi itu dibawa sampai mereka masuk Islam, maka turunlah ayat tersebut di atas (QS. al-Baqarah [2]: 178) yang menegaskan hukum qișās. ${ }^{52}$ Penulis memandang bahwa tanggapan al-Qurțubī terhadap sabāb nuzūl, ia memposisikan ayat ini yang menekankan prinsip keadilan atas kondisi saat itu dalam melakukan qișāṣ.

Bagi al-Qurțubī, penetapan qiṣās hanya diperuntukkan kepada wali orang yang terbunuh. Kepada merekalah diwajibkan atau penegakan qișass atau penegakan hukuman lainnya. Namun, tidak semua orang berani (mampu, atau memiliki nyali) untuk melakukan qișās. Oleh karena itu, mereka diperbolehkan untuk menyerahkan hukuman qișās ini kepada seorang pemimpin ataupun orang berani untuk melakukannya, dengan syarat bahwa hukuman yang diberikan tidak melebihi apa yang diharuskan sebagaimana mestinya. Adapun jika wali dari orang yang terbunuh ini rela untuk tidak dilaksanakan qișās, dengan pemaafan atau menggantinya dengan diyat maka itu juga diperbolehkan. $^{53}$

Jika ada yang mengatakan makna dari firman Allah swt., كَِبَ pada ayat ini al-Qurțubī menjelaskan bahwa diwajibkan atas kamu jika kamu menghendakinya. Dan ketahuilah bahwa qișās ini adalah sebuah jalan keluar dari suatu perdebatan (tentang apa hukuman yang seharusnya diberikan)." ${ }^{, 54}$ Kata لقَّلى (tebagaimana dikutip dari Ibn al-'Arabī yang dituliskan pada ayat ini bentuk jama' dari kata قتيل, yang di-ta'nith-kan karena tidak semua orang menyukainnya. Oleh karena itulah penulisannya ditetapkan seperti itu.

Dengan pola penafsiran yang diterapkannya itu, al-Qurțubī telah keluar dari pendapat kelompok Mālikīyyah, Shāfi'īyyah dan Hanābilah. Mereka menyatakan bahwa orang yang merdeka tidak dikenakan hukuman qișās jika ia membunuh hamba sahaya. Sejalan dengan pendapat kelompok Hanafìyah (seperti Imām al-Thawrī dan Ibn Abī Lailá, dan lainya). ${ }^{56}$ Hal ini, al- 
Qurțubī memberi maksud untuk menekankan konsep almusāwah (persamaan) terhadap praktek qiṣāṣ dilakukan orang Arab saat itu.

Pernyataan di atas membuktikan bahwa al-Qurțubī dalam menekankan konsep al-musāwah ia lebih condong memilih pendapat Hanafiyyah dan menolak pendapat Mālikīyyah, Shāfi'īyyah dan Hanābilah.

\section{Perintah Potong Tangan bagi Pencuri Laki-laki dan Pencuri Perempuan.}

Menurut al-Qurțubī QS. al-Mā'idah: $38-39^{57}$ ini menjelaskan tentang perintah potong tangan bagi pencuri lakilaki maupun pencuri perempuan. ${ }^{58}$ Firman Allah swt., وَالسَّارقُ

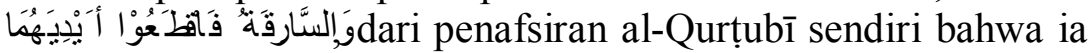
memulai dengan menjelaskan terkait penujukan makna. Karena zahirnya ayat menunjukkan bahwa hukuman ini umum dan mencakup semua orang yang melakukan pencurian, padahal

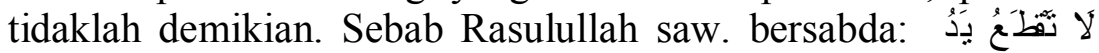
Jungan dipotong tangan seorang pencuri kecuali pada (pencurian) seperempat dinar atau lebih" ${ }^{59}$ Hadis ini sungguh jelas, karena tangan seorang pencuri tidak boleh dipotong kecuali pada pencurian seperempat dinar atau lebih, maksudnya adalah mencuri sesuatu yang nominalnya memenuhi kriteria yaitu mencapai seperempat dinar ${ }^{60}$ atau lebih. ${ }^{61}$ Dalam hal ini al-Qurțubī menggunakan hadis sebagai pemberi batasan terhadap kemutlakan ayat.

Mengutip hadis lain oleh Ibn 'Umar yang menyatakan bahwa "Pada masa Rasulullah saw., seorang lelaki mencuri sebuah hajafah (perisai) tidak dipotong tangannya." Kemudian Rasulullah saw. memerintahkan (agar perisai itu dinilai) dan perisai itu pun dinilai dengan tiga dirham. ${ }^{62}$ Namun nilai dari perisai itu banyak diperselisihkan oleh para sahabat dalam menentukan nominal. ${ }^{63}$

Dari perbedaan riwayat ini, al-Qurțubī mencoba mengumpulkan beberapa riwayat terkait nilai dari sebuah perisai manakah yang paling kuat untuk dijadikan dasar hukum. Sementara itu al-Shāfi' $\overline{1}$ menjadikan hadis ' $\overline{\mathrm{A}}$ 'ishah sebagai dasar hukum sekaligus menilai $\operatorname{marf}_{\bar{u}}$ ' hadis tersebut, dan dalam 
hal ini al-Shāfi' 1 meninggalkan hadis dari Ibn 'Umar. Alasannya adalah karena dia menilai para sahabat berbeda pendapat dalam menentukan nominal perisai yang dicuri itu. Ibn 'Umar mengatakan perisai itu tiga dirham, Ibn 'Abbās mengatakan sepuluh dirham, dan Anas mengatakan lima dirham. Sedangkan dalam riwayat ' $\bar{A}$ 'ishah tidak ada perselisihan tentang seperempat dinar, karena hadis ini dianggap șahịh-thābit. Jika berdasarkan kepada pendapat ini, apabila benda yang dicuri itu dinilai mencapai seperempat dinar, maka (tangan) orang yang mencurinya harus dipotong. Menurut Abū Hanīfah dan kedua sahabatnya serta al-Thawrī, nominalnya adalah sepuluh dirham. Pendapat yang diriwayatkan Abū Hurayrah dan Abī Sa'īd alKhuḍrī, tangan (pencuri) itu harus dipotong pada pencurian empat dirham atau lebih. Riwayat dari 'Abdullāh bin Zubayr yang dikutip oleh al-Qurțubī dari Jāmi' al-Bayān fì Tafsīr alQur'ān karya al-Ṭābarī menyatakan, satu dirham dapat dipotong tangan. ${ }^{64}$ Setelah memilah-milah berbagai pendapat, al-Qurțubī menyimpulkan bahwa pilihannya terhadap suatu riwayat adalah pendapat Imām al-Shāfi' '̄ berdasarkan pada hadis ' $\bar{A}$ 'ishah yang dinilai paling sahih.

Apabila hadis riwayat ' $\overline{\mathrm{A}}$ ' ishah dihadapkan pada hadis alBukhārī, Muslim dan lainnya meriwayatkan dari Abū Hurayrah,

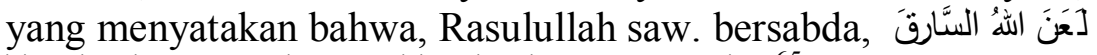

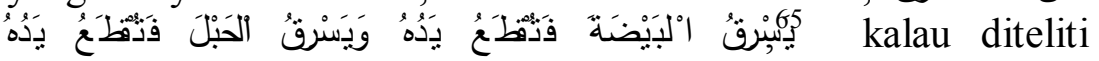
pernyataan hadis ini adalah bertentangan. Di mana hadis ini sesuai dengan zahir ayat tersebut, yaitu bahwa tangan itu harus dipotong pada pencurian yang sedikit dan pencurian yang banyak. Terhadap dua hadis tersebut, al-Qurțubī memberikan solusi yang menyatakan, bahwa sabda Rasulullah saw. tersebut merupakan 'peringatan'. Maksudnya, hukum atas pencurian yang sedikit itu sama saja dengan pencurian yang banyak, karena dikhawatirkan dari mulai hal yang kecil akan timbul pada pencurian yang lebih besar. ${ }^{66}$

Para ulama berbeda pendapat mengenai kewajiban membayar ganti kerugian (al-ghurm) oleh pencuri yang dipotong tangannya. apakah denda itu dijatuhkan bersama hukuman potong (tangan) ataukah tidak? Dari penafsiran ayat

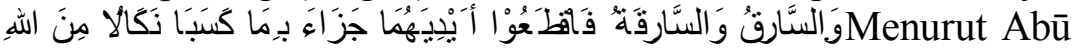


Hanīfah tidak wajib, karena denda itu sama sekali tidak menyatu dengan hukuman potong tangan. Sebab dalam ayat itu Allah swt. tidak menyebutkan denda. ${ }^{67}$ Imām al-Shāfi' 1 berpendapat, orang yang mencuri itu harus mengganti (membayar denda) atas yang dicurinya, jika dia seorang yang mampu. Jika dia adalah orang yang tidak mampu mengganti apa yang dicurinya, maka itu menjadi utang dalam tanggungannya, yang harus dibayar jika sudah mampu. Sebagaimana pendapat Aḥmad dan Ishāk. Sedangkan pendapat Imām Mālik dan sahabatnya, jika barang yang dicurinya itu masih ada, maka pencuri harus mengembalikannya (kepada pemiliknya). Tapi jika barang itu tidak ada atau rusak, jika dia mampu untuk menggantinya maka dia harus menggantinya. Tapi jika dia tidak mampu untuk menggantinya, maka itu tidak dianggap sebagai utangnya. Tidak boleh mengumpulkan dua hukuman terhadap satu kasus. Karena kewajiban pencuri untuk mengganti apa yang sudah dicurinya merupakan sebuah hukuman, dan potong tangan pun merupakan sebuah hukuman. Sebagaimana dinyatakan dalam hadis Rasulullah saw. yang diriwayatkan oleh al-Nasā'̄ dan al-

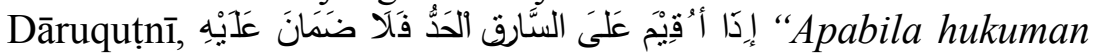
dijatuhkan kepada pencuri, maka dia tidak wajib membayar denda (mengganti apa yang sudah dicurinya)". 68 Dalam masalah ganti rugi ini, al-Qurțubī lebih memilih pendapat Imām al-Shāfi' 'i katimbang pendapat Imām Mālik.

Dari sekian perbedaan pendapat yang ada, al-Qurțubī tetap mengatakan bahwa pendapat yang sahịh (benar) adalah pendapat yang dikemukakan oleh al-Shāfi'ī dan orang-orang yang sependapat dengannya. Ia memberi alasan bahwa bagi alShāfi' '̄, hukuman yang dijatuhkan untuk Allah swt. itu tidak dapat menggugurkan (ketentuan) untuk mengganti sesuatu yang dirusak milik hamba-hamba-Nya. Hal tersebut berbeda dengan argumentasi yang dikemukakan oleh Imām Mālikī, al-Qurțub̄̄ menilai bahwa hadis yang diriwayatkan oleh al-Nasā'̄ dan alDāruquṭn̄ dari 'Abd al-Raḥman bin 'Awf tersebut tidak mengandung argumentasi apapun (tidak dapat dijadikan hujjah) karena tidak kuat. Menurut Ibn al-'Arabī, hadis ini bātill. ${ }^{69}$ Meskipun al-Qurțubī bermazhab Mālik̄̄, dalam penafsiran ayat tersebut ia tidak membela atau pun sejalan dengan pendapat 
Imām Mālik. Ini membuktikan bahwa al-Qurțubī lebih berhatihati dalam menyikapi suatu masalah yang tidak harus mementingkan mazhabnya.

\section{Ketentuan Hukuman Dera atau Rajam bagi Pezina.}

Pada penafsiran terkait perzinaan ini difokuskan pada ayat QS. al-Nūr: 2. Ayat ini yang berisi ketentuan hukuman dera bagi setiap pelakunya. ${ }^{70}$ Zina $^{71}$ telah dikenal dalam bangsa Arab sebelum munculnya agama Islam, seperti pencurian dan pembunuhan. Pengertian zina dalam perkara ini menurut alQurțubī adalah nama kata yang digunakan untuk mengungkapkan hubungan seks yang terjadi antara seorang lelaki dan perempuan di dalam bagian vagina tanpa ada ikatan pernikahan atau syubhat pernikahan dengan kerelaannya. ${ }^{72} \mathrm{Jika}$ mau, maka dapat dikatakan bahwa zina adalah memasukkan kemaluan laki-laki ke dalam kemaluan perempuan yang dikehendaki secara naluri dan diharamkan oleh agama. ${ }^{73}$ Jika itu yang terjadi, maka hukum had wajib dilaksanakan terhadap pelakunya. ${ }^{74}$

Firman Allah swt., مِائَة جَلَّةٍ "Seratus kali dera", adalah hukuman bagi pezina laki-laki yang merdeka, baligh dan bujang. Demikian juga dengan pezina perempuan yang sudah baligh, perawan dan merdeka. Sementara dalam sunnah ditetapkan hukuman diasingkan selama satu tahun, namun para ulama masih berbeda pendapat tentang hal itu. Adapun budak perempuan yang dimiliki, hukuman baginya adalah didera 50 kali. Hal ini berdasarkan kepada firman Allah swt., فَإِنْ أَتَيْنَ Kemudian mereka melakukan perbuatan yang keji (zina), maka atas mereka separuh hukuman dari hukuman wanita-wanita merdeka yang bersuami." (QS. al-Nisā': 25).

Menurut al-Qurțubī adapun laki-laki yang sudah menikah dan merdeka, jika dia melakukan perzinaan, maka hukuman baginya adalah dirajam, bukan didera. Namun sebagian ulama ada yang mengatakan bahwa dia harus didera seratus kali, kemudian dirajam. Semua ini telah dikemukakan secara jelas dengan surat al-Nisā', sehingga tidak perlu diulangi kembali. ${ }^{75}$

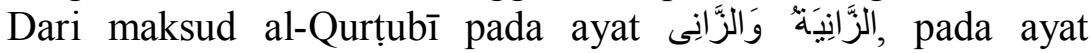


tersebut dimaksudkan agar jangan sampai ada dugaan bahwa hanya pihak laki-laki saja yang terkena had sedangkan perempuan tidak, dengan alasan karena perempuan hanya menjadi sasaran pelampiasan nafsu padahal perzinaan itu dilakukan atas kemauan kedua belah pihak. Allah swt. menyebutkan pezina laki-laki dan pezina perempuan, karena menurut satu pendapat, Allah swt. menyebutkan keduanya supaya memberikan unsur penekanan. ${ }^{76}$

Adapun menurut al-Qurțubī mengenai qirā'ah terhadap

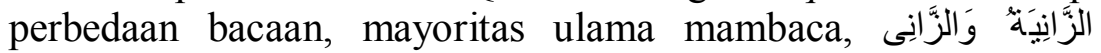
dengan harakat dhammah di akhir kata. Sedangkan 'Isá bin 'Umar al-Thaqafi membacanya الزَّاذيَّة - yakni dengan harakat fathah di akhir kata. ${ }^{77}$

Hal itu menunujukkan bahwa hukuman dera itu bersifat 'àmmah (umum) umum untuk semua pezina. Karena pada

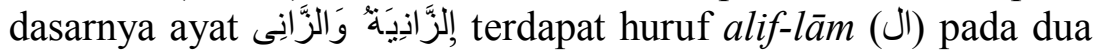
kata itu juga menunjukkan makna 'àmm (umum) meliputi semua orang yang berbuat zina. Adapun mayoritas mufassir berkata, ayat itu berlaku khusus untuk bujang dan perawan (laki-laki merdeka dan perempuan merdeka). "Mereka beragumentasi bahwa hukuman itu tidak bersifat umum bagi budak yang melakukan zina. Ini berarti hukuman yang harus diterapkan bagi mereka adalah setengah dari orang yang merdeka, seperti dijelaskan dalam QS. al-Nisā': 16.

Adapun pokok penting dalam penafsiran al-Qurțubī adalah tentang siapa yang harus melakukan hukuman itu. Menurutnya, tidak ada perbedaan pendapat bahwa sosok yang diperintahkan untuk melakukan perintah menjatuhkan hukuman dera ini adalah al-imām (pemerintah) dan orang-orang yang berada pada posisinya. ${ }^{78}$ Begitu juga dengan pendapat Mālik dan al-Shāfi'’ menambahkan, "Seorang tuan juga, jika yang melakukan zina adalah budaknya." ${ }^{, 79}$ Menurut satu pendapat, al-Qurțubī mengutip pernyataan al-Rāzī. Sosok yang diperintahkan untuk melaksanakan perintah menjatuhkan hukuman dera adalah seluruh kaum Muslim. Sebab menegakkan hukum-hukum agama merupakan kewajiban kaum Muslim, kemudian al-imām (pemerintah) mewakili mereka, sebab mereka tidak mungkin 
berkumpul atau menyatu untuk melaksanakan hukuman tersebut. $^{80}$

Allah swt. juga telah menetapkan ketetapan (hukuman) dalam kasus meminum khamer sebanyak delapan kali cambukan. Di mana hal ini dilakukan melalui tindakan 'Umar yang berlaku di kalangan para sahabat. 'Umar pernah dihadapkan seseorang yang mabuk di Bulan Ramadan, kemudian Umar mencambuknya seratus kali. ${ }^{81}$ Delapan puluh kali cambukan sebagai had karena meminum khamer, dan dua puluh lainnya karena dia telah melanggar kehormatan bulan Ramadan. $^{82}$ Menurut al-Qurțubī, bagi pelaku hukuman meminum khamer diperberatkan menjadi delapan puluh kali cambuk. Dalam penafsiran al-Qurțub̄i ia melihat kasus zina dengan kasus minum khamer, ia telah membandingkan jumlah cambukan yang harus diberikan kepada sang pelaku. Melalui sebuah riwayat al-Qurțubī menjelaskan, al-Darāquṭn̄̄ meriwayatkan bahwa Qāọ̄i al-Ḥusain bin Ismāil menceritakan kepada kami, Șafwan bin 'Isá menceritakan kepada kami dari alZuhrī, dia berkata: 'Abd al-Raḥmān bin Azhār mengabarkan kepadaku, dia berkata, "Aku melihat Rasulullah saw. pada peristiwa perang Hunain sedang berada di tengah orang-orang, menanyakan rumah Khālid bin al-Wālid. Kepada beliau kemudian dihadapkan seseorang yang sedang mabuk. Beliau kemudian mencambuki orang itu empat puluh kali." 83

Kesimpulan penulis, sebagaimana dalam penafsiran alQurțubī QS. al-Nūr: 2, bagi pezina laki-laki (bujang) dan perempuan (perawan) seratus kali dera. Demikian pezina lakilaki dan perempuan yang sudah menikah, menurut al-Qurțubī dirajam bukan didera. Adapun yang melakukan hukuman dera adalah al-imām (pemerintah), bagi al-Qurțubī yang menjatuhkan hukuman dera adalah seluruh kaum Muslim, hanya saja adanya al-imām (pemerintah) sebagai representasi masyarakat.

\section{E. Kesimpulan}

Dari penjelasan di atas dapat disimpulkan bahwa penafsiran hukum al-Qurțubī selalu diawali dengan penjelasan hadis yang menjadi dasar penafsiran hukum para ulama. Kemudian ia membandingkan dengan penafsiran ulama lain 
mengenai ayat yang ditafsirkan. Di akhir penafsirannya alQurțubī memberikan dalil yang ia pilih dari para ulama fikih yang ia kutip, sekalipun berbeda mazhab dengannya, apabila itu dianggap paling sahih ia akan mengambil pendapat tersebut. Ini membuktikan bahwa al-Qurțubī lebih subjetif ketika mengambil pendapat dari mazhab-mazhab, walaupun jati dirinya pengikut mazhab tertentu.

${ }^{1}$ Muḥammad 'Alī al-Șābūn̄̄, al-Tibyān fì 'Ulūm al-Qur'ān, terj. Moh. Chudory dan Moh. Mastua HS (Bandung: Al-Ma'ruf, 1970), h. 199.

${ }^{2}$ Tafsìr bi al-Ma'thūr ialah tafsir yang berlandaskan pada al-Qur'an atau riwayat yang shahih sesuai urutan yang telah disebutka di muka dalam syarat-syarat mufassir. Yaitu menafsirkan al-Qur'an dengan al-Qur'an (ayat dengan ayat), al-Qur'an dengan Sunnah, perkataan sahabat karena merekalah yang paling mengetahui Kitabullah, atau dengan pendapat tokoh-tokoh besar tabi' in. Pada umumnya mereka menerimanya dari para sahabat. Lihat Mannāe Khalīl al-Qatțān, Pengantar Studi Ilmu Al-Qur'an, terj. Aunur Rafiq ElMazni (Jakarta: Pustaka Al-Kautsar, 2009), cet. 4, h. 434.

${ }^{3}$ Tafsīr bi al-Ra'yi ialah tafsir yang di dalam menjelaskan maknanya atau maksudnya, mufassir hanya berpegang pada pemahamannya sendiri, pengambilan kesimpulan (istinbaț) pun berdasarkan pada logikanya semata. Kategori penafsiran seperti ini dalam memahami al-Qur'an tidak sesuai dengan ruh syari'at yang didasarkan pada nash-nashnya. Rasio semata yang tidak disertai bukti-bukti akan berakibat pada penyimpangan terhadap Kitabullah. Kebanyakan orang yang melakukan penafsiran demikian adalah ahli bid'ah, penganut mazhab yang bathil. Mannāe Khalīl al-Qațāan, Pengantar Studi Ilmu Al-Qur'an, h. 440.

${ }^{4}$ Man̄̄e 'Abd Halim Maḥmūd, Manhaj al-Mufassirīn, terj. Faisal Saleh dan Syahdianor (Maktabah al-Aimān, 2003), h. vii-viii.

${ }^{5}$ Ignaz Goldziher, Mazhab Tafsir: Dari Klasik Hingga Modern, terj. M. Alaika Salamullah, dkk (Sleman Yogyakarta: eLSAQ Press, 2003), cet. I, h. 120 .

${ }^{6}$ Ahmad al-Syirbashi, Sejarah Tafsir al-Qur'an, terj. Amak Baldjun (Jakarta: Pustaka Firdaus, 1994), cet. III, h. 117.

7 Shohibul Adib, dkk., Ulum al-Qur'an: Profil Para Mufassir alQur'an dan Para Pengkajinya (Tangerang Selatan: Pustaka Dunia, 2011), Cet. I, h. Xv.

${ }^{8}$ Hasbi Ash-Shiddieqy, Sejarah dan Pengantar Ilmu al-Qur'an dan Tafsir (Semarang: PT. Pustaka Rizki Putra, 2011), cet. IV, h. 213. 
${ }^{9}$ Hasbi Ash-Shiddieqy, Sejarah dan Pengantar Ilmu al-Qur'an dan Tafsir, h. 214.

${ }^{10}$ Ibn al-'Arābī menyebutkan bahwa tafsir sufi adalah tafsir yang ditulis sesuai dengan pandangan sufistik seorang sufi. Lihat Mannā' Khalīl al-Qațạn, Mabāhith fì 'Ulūm al-Qur'ān (Riyād: Manșūrāt al-'Așr al-Ḥādīth, 1973), h. 356.

${ }^{11}$ Al-Dzahabī menjelaskan ada dua varian dalam tafsir sufistik, yaitu tafsir sufi nadhārī dan sufi isyārī ('amalī). Dalam tafsir sufi nadhārī, seorang sufi membangun doktrin sufismenya secara teoritis, baru kemudian ia mencari ayat al-Qur'an dan memproduksi sebuah penafsiran yang sesuai dengan pandangan tersebut, sebagaimana yang telah dilakukan oleh Ibn al'Arābī. Sedangkan tafsir sufi isyārī ('amalī), seorang sufi berusaha menakwilkan atau memberikan makna batin dari masing-masing ayat atau beberapa ayat-ayat al-Qur'an yang akan ia tafsirkan yang bersumber dari isyarat batin. Melalui isyarat batin ini hanya bisa dilakukan oleh para pengembara rohani, dalam istilah tasawufnya adalah sālik. Lihat Husain alDzahabī, al-Tafsìr wa al-Mufassirūn, juz 2, h. 261.

12 'Abd al-Hayy al-Fārmawī, Metode Tafsir Maudhu'i, terj. Rosihon Anwar (Bandung: Pustaka Setia, 2002), cet. I, h. 27-37.

13 'Abd al-Hayy al-Fārmawī, Metode Tafsir Maudhu'i, h. 30.

14 M. Quraish Shihab, dkk., Sejarah dan Ulum al-Qur'an (Jakarta: Pustaka Firdaus, 2008), cet. IV, h. 179.

${ }^{15}$ M. Quraish Shihab, dkk., Sejarah dan Ulum al-Qur'an, h. 180.

${ }^{16}$ M. Quraish Shihab, Membumikan al-Qur'an (Bandung: Mizan, 1992), Cet. ke-26, h. 72-73.

17 Mannāe Khalīl al-Qatțān, Pengantar Studi Ilmu Al-Qur'an, terj. Aunur Rafiq El-Mazni (Jakarta: Pustaka Al-Kautsar, 2009), cet. 4, h. 469.

${ }^{18}$ Hasbi Ash-Shiddieqy, Sejarah dan Pengantar Ilmu al-Qur'an dan Tafsir, h. 211.

19 Muhammad Amin Suma, Tafsir Ahkam - Ayat-ayat Ibadah (Jakarta: PT Logos Wacana Ilmu, 1997), cet. I, Juz, I, h. 2.

${ }^{20}$ Muhammad Amin Suma, Pengantar Tafsir Ahkam (Jakarta: PT RajaGrafindo Persada, 2001), cet. I, h. 150 \& 152.

21 Muhammad Husain al-Dzahabī, al-Tafsīr wa al-Mufassirūn (Kairo: Maktabah Wahbah, 1994), h. 439.

${ }^{22}$ Al-Kiyā al-Haras̄̄, Aḥkām al-Qur'ān, Taḥqīq: Mūsá Muḥammad 'Alī 'Abd 'Ațiyyah, (Kairo: Dār al-Kutub al-Hādīthah, 1974), h. 2.

${ }^{23}$ Manī' 'Abd Halim Maḥmūd, Manhāj al-Mufassirīn, h. 246.

24 Azman Abdurrahman dan Zulkifli Hasan, Metode Ibn al-'Arabī dalam Kitab Tafsir “Ahkam al-Qur'an dan Hubungannya dengan Metode Penafsiran Masa kini (Malaysia: Fakultas Syariah dan Undang-undang Universitas Islam Malaysia, t,t.), h. 2.

25 Muhammad 'Al̄̄ Iyāzī, al-Mufassirūn Hayatuhum wa Manhajuhum (Teheran: Mu'assasah al-Țibā'ah wa al-Nashr, 1414 H), h. 410. 
26 Faizah Ali Syibromalisi dan Jauhar Azizy, Membahas Kitab Tafsir Klasik-Modern (Jakarta: Lembaga Penelitian UIN Syarif Hidayatullah Jakarta, 2011), h. 19.

27 Muhammad 'Alī Iyāzī, al-Mufassirūn Hayatuhum wa Manhājuhum (Teheran: Mu'assasah al-Ṭibā'ah wa al-Nashr, 1414 H), h. 408.

${ }^{28}$ Muhammad Hādī Ma'rifah, al-Tafsìr wa al-Mufassirūn fì Thaubīh al-Qashīb (Iran, al-Jāmi'ah al-Raḍuwīyyah li al-'Ulūm al-Islamīyyah, 1426 H.), Juz. II, h. 768.

${ }^{29}$ Shohibul Adib, dkk., Ulum al-Qur'an - Profil Para Mufassir alQur'an dan Para Pengkajinya (Tangerang Selatan: Pustaka Dunia, 2011), cet. I, h. 75

${ }^{30}$ Muḥammad 'Alī Iyāz̄i, al-Mufassirūn Hayatuhum..., h. 409.

31 Al-Qașabī Maḥmūd Zalaț, al-Qurțubī wa Manhajuhu fì Tafsīr, (Kuwait: Dār al-Qalam, 1981), h. 6 dan 30.

32 Mohammad Anwar Syarifuddin, "Metodologi Penelitian Tafsir Hadis, (UIN Syarif Hidayatullah)” artikel diakses 9 februari 2013 dari http://anwarsy. files.wordpress.com/2010/03/mpth-slide.pdf, h. 34.

33 Rashād Hasan Khalīl, Tārīkh Tashrī’ al-Islamī, terj. Nadirsyah Hawari (Jakarta: Amzah, 2009), h. 182.

${ }^{34}$ Badri Yatim, Sejarah Peradaban Islam (Jakarta: Rajawali Press, 2000), h. cet. 11 102-103.

35 Philip K. Hitti, History of The Arabs, terj. R. Cecep Lukman Hakim dan Dedi Slamet Riyadi (Jakarta: Serambi, 2006), h. 690.

${ }^{36}$ Al-Qaṣabī Mạ̣mūd Zalaṭ, al-Qurțubī wa Manhajuhu fì Tafsīr, h. 344.

${ }^{37}$ Ahmad 'Isá Yūsuf al-'Isá, al-Arā al-Ușūliyyatī li Imām al-Qurtubì min Khilāli Tafsìrihi (Beirut Lebanon: Dār al-Kutub al-'Ismiyyah 2005), h. 31-32.

${ }^{38}$ Aḥmad 'Isá Yūsuf al-'Isá, al-Arā al-Ușūliyyatī..., h. 32-34.

39 Al-Qurțubī, al-Jāmi', Juz. I, h. xvii.

${ }^{40}$ Ahmad Iftah Sidik, "Tafsir al-Qurțubī: Tafsir Hukum Terbaik dari Abad Pertengahan," artikel diakses pada 4 januari 2013 dari http:/www.thohiriyyah.com/2010/10/tafsir-al-qurthubi-tafsir-hukum-terbaikdari-abad-pertengahan.html

${ }^{41}$ Al-Qurțubī, al-Jāmi', Juz. I, h. xvii.

${ }^{42}$ QS. al-Baqarah: 223.

${ }^{43}$ Al-Qurțubī, al-Jāmi', juz. IV, h. 10., dan lihat terjemahan, Juz. III, h. 206. Lihat juga Mohammad Arja Imroni, "Corak Tafsir Ayat Aḥām AlQurțubī” (Disertasi Program Pasca Sarjana UIN Syarif Hidayatullah Jakarta, 2008 ), h. 73.

${ }^{44}$ QS. al-Baqarah [2]: 221.

45 Al-Qurțubī, al-Jāmi', Juz III, h. 473. Lihat juga Faizah Ali Syibromalisi dan Jauhar Azizy, Membahas Kitab Tafsir Klasik-Modern (Jakarta: Lembaga Penelitian UIN Syarif Hidayatullah Jakarta, 2011), h. 25. 
46 “Diwajibkan atas kamu qișāṣ berkenaan dengan orang-orang yang dibunuh; orang merdeka dengan orang merdeka, hamba dengan hamba, dan wanita dengan wanita. Maka barangsiapa yang mendapat suatu pemaafan dari saudaranya." Lihat al-Bukhārī, Saḥ̄̄h al-Bukhārī, no. 4498,

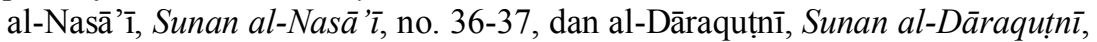
no. 199

${ }^{47}$ Al-Qurțubī, al-Jāmi', Juz.II, h. 561.

${ }^{48}$ Al-Bukhārī, Șaḥ̄ḥ al-Bukhārī, no. 4498, Juz. III, h. 102.

${ }^{49}$ Al-Qurțubī, al-Jāmi', Juz.II, h. 562.

${ }^{50}$ Lihat al-Jașsāṣ, Ahk kām al-Qur'ān, Juz. I, h. 134. dan al-Ṭābarī , Jāmi al-Bayān fì Tafsìr al-Qur'ān, Juz. I, h. 42.

51 "sesungguhnya orang yang paling takabbur dihadapan Allah pada hari kiamat nanti ada tiga: seseorang yang membunuh (mengqișās) selain pembunuh (yang sebenarnya), lalu seseorang yang membunuh di tanah haram, dan seseorang yang mengambil tebusan (atas suatu pembunuhan atau kejahatan lainnya) dengan cara jahiliyah." Hadis diriwayatkan Ibn Abī Shaibah 14/487 dan HR. Ahmmad dalam musnadnya no. (6681 dan 6757).

52 Al-Qurțubī tidak menyebutkan secara detail terkait sebab nuzul, sebab nuzul ini dirujuk pada K.H. Q Shaleh, dkk., Asbabun Nuzul - Latar Belakang Historis Turunnya Ayat-ayat al-Qur'an, Bandung: Diponegoro 2000, h. 50.

${ }^{53}$ Al-Qurțubī, al-Jāmi', Juz II, h. 564.
${ }^{54}$ Al-Qurțub̄i, al-Jāmi', Juz. II, h. 564.
${ }^{55}$ Ibn al-'Arabī, Aḥkām al-Qur'ān, juz. 1, h. 61.

56 Pendapat ini juga diikuti oleh Dāwud, Sa'id bin Musayyab, Qatādah, Ibrāhīm, an-Nakhā'̄̄, dan al-Ahkām bin Uyaynah. Pendapat ini juga didasari oleh pendapat dari 'Alī dan Ibn Mas'ūd. Al-Qurțubī, al-Jāmi', Juz. II, h. 566.

57 "Laki-laki yang mencuri dan perempuan yang mencuri, potonglah tangan keduanya (sebagai) pembalasan bagi apa yang mereka kerjakan dan sebagai siksaan dari Allah. dan Allah Maha Perkasa lagi Maha Bijaksana.Maka Barangsiapa bertaubat (di antara pencuri-pencuri itu) sesudah melakukan kejahatan itu dan memperbaiki diri, Maka Sesungguhnya Allah menerima taubatnya. Sesungguhnya Allah Maha Pengampun lagi Maha Penyayang. "' (QS. al-Mā'idah: 38-39)

${ }^{58}$ Al-Qurțubī, al-Jāmi', Juz VI, h. 380.

${ }^{59}$ Hadis ini diriwayatkan oleh Imām al-Bukhārī, Saḥ̄h al-Bukhārī, Bab Qawlillāh Ta’ālá al-Sāriq wa al-Sāriqah, hadis no. 6291, 6292, 6293 dan Imām Muslim, Saḥ̄ḥ Muslim, Bab Had Sāriqah wa Niṣabuhā, hadis no. 3189-3191. Semua melalui jalur 'A'’ishah.

${ }^{60}$ Seperempat dinar dirupiahkan sekarang sekitar $400.000-500.000$ ribu rupiah. Tapi nilai bisa bertambah atau berkurang, tergantung nilai jual emas. 
${ }^{61}$ Al-Qurțubī, al-Jāmi ', Juz VI, h. 381.

62 Tiga dirham dirupiahkan sekarang sekitar 210. 000 ribu rupiah. Tapi nilai bisa bertambah atau berkurang, tergantung nilai jual perak. Hadis ini diriwayatkan oleh Imām al-Bukhārī, Șah̄ịh al-Bukhārī, no. 6795, dan Imām Muslim, Sạ̣̄ḥ Muslim, no. 1686.

${ }^{63}$ Al-Qurțubī, al-Jāmi', Juz. VI, h. 382.

${ }^{64}$ Al-Qurțubī, al-Jāmi', Juz. VI, h. 383-384.

65 "Allah melaknat pencuri yang mencuri pelindung kepala (topi baja) kemudian tangannya dipotong, dan mencuri tali kemudian tangannya dipotong". Hadis ini diriwayatkan Imām al-Bukhārī, Sạ̣̣̣̄ al-Bukhārī, no. 6285, dan Imām Muslim, Șaḥịh Muslim, no. 3195.

${ }^{66}$ Al-Qurțubī, al-Jāmi', Juz. VI, h. 385-386.

${ }^{67}$ Ibn al-'Arabī, Ahkām al-Qur'ān, Juz. II, h. 609.

${ }^{68}$ Al-Qurțubī, al-Jāmi', Juz. VI, h. 395.

${ }^{69}$ Al-Qurțubī, al-Jāmi', Juz. VI, h. 396.

${ }^{70}$ Al-Qurțubī, al-Jāmi', Juz XII, h. 416.

71 Perzinaan adalah hubungan kelamin yang terjadi antara seorang pria dengan seorang wanita yang tidak diikat oleh hubungan perkawinan yang sah. Ini adalah suatu perbuatan pidana yang diancam dengan sanksi had dengan cambuk (jild) 100 kali untuk masing-masing pihak. Pelaksana sanksi adalah penguasa (hakim) atau orang yang berwenang untuk itu (al-Nūr:2). Lihat Abdul Halim Barkatullah dan Teguh Prasetyo, Hukum IslamMenjawab Tantangan Zaman Yang Terus Berkembang (Yogyakarta: Pustaka Pelajar Offset, 2006), cet. I, h. 265-268.

${ }^{72}$ Al-Ṭābarī, Ahkām al-Qur'ān, Juz IV, h. 287.

73 Al-Rāzì, Mafātih al-Ghayb, Juz 23, h. 131.

${ }^{74}$ Al-Qurțubī, al-Jāmi', Juz XII, h. 416.

${ }^{75}$ Al-Qurțubī, al-Jāmi', Juz XII, h. 417.

${ }^{76}$ Unsur penekanan yang dimaksud sebagaimana firman Allah swt, Laki-laki yang mencuri dan perempuan yang mencuri, potonglah tangan keduanya." (QS. al-Mā'idah: 38). Lihat alQurțubī, al-Jāmi', Juz XII, h. 418.

7 Menurut Sibawaīh, qirā'ah ini lebih baik. Sebab menurutnya, susunan firman Allah swt. itu adalah seperti kalimat, زَيْدًا اضْربْ (kepada Zaid pukullah). Adapun alasan dibaca dengan harakat dhammah, menurut Sibawaîh itu karena lafaz tersebut menjadi khabar mubtada', di mana

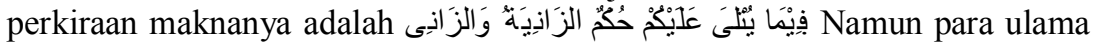
sepakat atas qirā'ah dengan harakat dhammah, meskipun menurut Sibawaīh, jika mengikuti aturan dalam ilmu Nahwu seharusnya lafaz tersebut dibaca dengan harakat fathah.

\footnotetext{
${ }^{78}$ Al-Qurțubī, al-Jāmi', Juz XII, h. 421.

${ }^{79}$ Ibn al-'Arabī, Ahkām al-Qur'ān, Juz. III, h. 1314.

${ }^{80}$ Al-Qurțubī, al-Jāmi', Juz XII, h. 421.

${ }^{81}$ Diriwayatkan Ibn Abī Shaibah, 10/53.
} 
${ }^{82}$ Al-Qurțubī, al-Jāmi', Juz XII, h. 428-429.
${ }^{83}$ Al-Qurtubī, al-Jāmi', Juz XII, h. 429.

\section{REFRENSI}

Muḥammad 'Alī al-Ṣābūn̄̄, al-Tibyān fì 'Ulūm al-Qur'ān, terj. Moh. Chudory dan Moh. Mastua HS (Bandung: AlMa'ruf, 1970

Khalīl al-Qațtān, Pengantar Studi Ilmu Al-Qur'an, terj. Aunur Rafiq El-Mazni (Jakarta: Pustaka Al-Kautsar, 2009

Abd al-Hayy al-Fārmaw̄in, Metode Tafsir Maudhu'i, terj. Rosihon Anwar (Bandung: Pustaka Setia, 2002

Ignaz Goldziher, Mazhab Tafsir: Dari Klasik Hingga Modern, terj. M. Alaika Salamullah, dkk Sleman Yogyakarta: eLSAQ Press, 2003

Man̄̄e 'Abd Halim Maḥmūd, Manhaj al-Mufassirīn, terj. Faisal Saleh dan Syahdianor Maktabah al-Aimān, 2003

Faizah Ali Syibromalisi dan Jauhar Azizy, Membahas Kitab Tafsir Klasik-Modern (Jakarta: Lembaga Penelitian UIN Syarif Hidayatullah Jakarta, 2011

Abdul Halim Barkatullah dan Teguh Prasetyo, Hukum IslamMenjawab Tantangan Zaman Yang Terus Berkembang (Yogyakarta: Pustaka Pelajar Offset, 2006

Azman Abdurrahman dan Zulkifli Hasan, Metode Ibn al- 'Arab̄̄ dalam Kitab Tafsir "Ahkam al-Qur'an dan Hubungannya dengan Metode Penafsiran Masa kini Malaysia: Fakultas Syariah dan Undang-undang Universitas Islam Malaysia, $\mathrm{t}, \mathrm{t}$

K.H. Q Shaleh, dkk., Asbabun Nuzul - Latar Belakang Historis Turunnya Ayat-ayat al-Qur'an, Bandung: Diponegoro 2000

Mohammad Arja Imroni, "Corak Tafsir Ayat Aḥkām AlQurțub ’’ Disertasi Program Pasca Sarjana UIN Syarif Hidayatullah Jakarta, 2008 
M. Najib Tsauri, Inkonsistensi Mazhab Dalam Penafsiran Ayat-Ayat ... | 91

Muḥammad 'Alī Iyāzī, al-Mufassirūn Hayatuhum wa Manhajuhum Teheran: Mu'assasah al-Ṭibā'ah wa alNashr, 1414 H

Aḥmad 'Isá Yūsuf al-'Isá, al-Arā al-Ușūliyyatī li Imām alQurțub̄ min Khilāli Tafsīrihi Beirut Lebanon: Dār alKutub al-'Ismiyyah 2005 